\title{
Production and characterization of a tributyrin esterase from Lactobacillus plantarum suitable for cheese lipolysis
}

\author{
M. Esteban-Torres, ${ }^{*}$ J. M. Mancheño,† B. de las Rivas, ${ }^{*}$ and R. Muñoz ${ }^{* 1}$ \\ *Laboratorio de Biotecnología Bacteriana, Instituto de Ciencia y Tecnología de Alimentos y Nutrición-Consejo Superior \\ de Investigaciones Científicas (ICTAN-CSIC), Juan de la Cierva 3, 28006 Madrid, Spain \\ †Grupo de Cristalografía y Biología Estructural, Instituto de Química-Física "Rocasolano"-Consejo Superior \\ de Investigaciones Científicas (IQFR-CSIC), Serrano 117, 28006 Madrid, Spain
}

\section{ABSTRACT}

Lactobacillus plantarum is a lactic acid bacterium that can be found during cheese ripening. Lipolysis of milk triacylglycerols to free fatty acids during cheese ripening has fundamental consequences on cheese flavor. In the present study, the gene $l p \_1760$, encoding a putative esterase or lipase, was cloned and expressed in Escherichia coli BL21 (DE3) and the overproduced Lp_1760 protein was biochemically characterized. Lp_1760 hydrolyzed $p$-nitrophenyl esters of fatty acids from $\mathrm{C} 2$ to $\mathrm{C} 16$, with a preference for $p$-nitrophenyl butyrate. On triglycerides, Lp_1760 showed higher activity on tributyrin than on triacetin. Although optimal conditions for activity were $45^{\circ} \mathrm{C}$ and $\mathrm{pH}$ 7, Lp_1760 retains activity under conditions commonly found during cheese making and ripening. The Lp_1760 showed more than $50 \%$ activity at $5^{\circ} \mathrm{C}$ and exhibited thermal stability at high temperatures. Enzymatic activity was strongly inhibited by sodium dodecyl sulfate and phenylmethylsulfonyl fluoride. The Lp_1760 tributyrin esterase showed high activity in the presence of $\mathrm{NaCl}$, lactic acid, and calcium chloride. The results suggest that Lp_1760 might be a useful tributyrin esterase to be used in cheese manufacturing.

Key words: lipolysis, cheese ripening, aroma, triacylglycerol, lactic acid bacteria

\section{INTRODUCTION}

The characteristic flavor of cheese is the result of the breakdown of protein, fat, and carbohydrates by native milk enzymes, added enzymes, starter bacteria, and the secondary microbiota of cheese (Fox and Wallace, 1997). Lipolysis of milk triacylglycerols to FFA during cheese ripening is an important biochemical process that contributes directly to its sensory characteristics

Received April 14, 2014

Accepted July 24, 2014.

${ }^{1}$ Corresponding author: r.munoz@csic.es
(Collins et al., 2003). Free fatty acids are important sensory compounds by themselves, and also as precursors of other volatiles and esters (McSweeney and Sousa, 2000). The release of FFA during cheese ripening by the combined action of lipolytic enzymes contributes to the development of flavor. Lipolytic enzymes include lipases, which catalyze the hydrolysis of water-insoluble long-chain triglycerols. The contribution of the native milk lipase to lipolysis in cheese is significant only in these varieties produced with raw milk, as this enzyme is inactivated during heat treatment. In other varieties, such as Cheddar cheese, only a low level of milk fat hydrolysis occurs due to the weak lipolytic activities of the starter and nonstarter bacteria (Crow et al., 1994).

Lactic acid bacteria are a source of esterase and lipases. Enzymes from Lactococcus lactis (Tsakalidou and Kalantzopoulos, 1992; Holland and Coolbear, 1996; Fernández et al., 2000), Lactobacillus casei (Castillo et al., 1999), Lactobacillus fermentum (Gobbetti et al., 1997), Streptococcus thermophilus (Liu et al., 2001), and Micrococcus spp. (Fernández et al., 2004) have been purified and characterized. Likewise, esterases and lipases from Lactobacillus plantarum have been partially purified (Andersen et al., 1995), purified (Oterholm et al., 1972; Gobbetti et al., 1996; Gobbetti et al., 1997; Lopes et al., 2002), or recombinantly produced (Brod et al., 2010; Benavente et al., 2013; Esteban-Torres et al., 2013; Navarro-González et al., 2013). Among the lipases described from $L b$. plantarum (Oterholm et al., 1967, 1968; Andersen et al., 1995; Gobbetti et al., 1996, 1997; Lopes et al., 1999, 2002), none have been genetically identified so far.

The genome sequence of $L b$. plantarum WCFS1 was published in 2003 (Kleerebezem et al., 2003) and more than 20 putative esterase or lipase genes were annotated on the basis of similarity searches. Although an operational distinction is made between esterases, which preferentially break the ester bonds of shorter chain acyl substrates at least partly soluble in water, and lipases, which display maximal activity toward water-insoluble long-chain triglycerides, no fundamental biochemical difference exists (Bornscheuer, 2002). 
From a structural viewpoint, both esterases and lipases are members of the $\alpha$ or $\beta$ hydrolase superfamily and share common catalytic machinery for ester hydrolysis and formation (Bornscheuer, 2002). Classifications based on sequence similarities do not separate the 2 classes of enzymes. The definitive approach to assigning a specific molecular function to a predicted open reading frame is to biochemically characterize the corresponding protein.

In this regard, the objective of the current study was to determine the functional features of the putative esterase or lipase Lp_1760 from Lb. plantarum WCFS1 through biochemical characterization of the recombinantly expressed protein. With a view to applying this esterase under conditions found during cheese making and ripening, enzyme activity under physicochemical conditions frequently encountered in cheese was studied.

\section{MATERIALS AND METHODS}

\section{Bacterial Strains, Plasmids, Growth Media, and Materials}

Lactobacillus plantarum WCFS1 used through the current study was provided by M. Kleerebezem (Nizo Food Research, Wageningen, the Netherlands). Escherichia coli DH10B was used as host strain for all DNA manipulations. Escherichia coli BL21 (DE3) was used for heterologous expression in the pURI3-Cter vector (Curiel et al., 2011). The Lb. plantarum strain was grown in de Man, Rogosa, Sharpe medium (Pronadisa, Madrid, Spain) adjusted to $\mathrm{pH} 6.5$ and incubated at $30^{\circ} \mathrm{C}$. Escherichia coli strains were cultured in LuriaBertani medium at $37^{\circ} \mathrm{C}$ with shaking at $200 \mathrm{rpm}$. When required, ampicillin was added to the medium at a concentration of $100 \mu \mathrm{g} / \mathrm{mL}$.

Plasmid DNA was extracted by a High Pure Plasmid Isolation Kit (Roche, Mannheim, Germany). The PCR product was purified with a QIAquick gel extraction kit (Qiagen, Hilden, Germany). Oligonucleotides were purchased from Eurofins MWG Operon (Ebersberg, Germany). DpnI and HS Prime Star DNA polymerase were obtained from TaKaRa (Shiga, Japan). His-tagged protein was purified by a Talon Superflow resin (Clontech, Mountain View, CA).

\section{Lp_1760 Gene Cloning and Expression}

Genomic DNA from Lb. plantarum WCFS1 was extracted. The gene encoding a putative lipase or esterase $\left(l p \_1760\right)$ in $L b$. plantarum WCFS1 was amplified by PCR by using the primers $1220\left(5^{\prime}-T A A C T T T A-\right.$ AGAAGGAGATATACATatgatcaaagttactaaccgacact) and 1221 (5'-GCTATTAATGATGATGATGATGATGatttaaataataatcgaagaaatt; the nucleotides pairing the expression vector sequence are indicated in italics and the nucleotides pairing the $l p_{-} 1760$ gene sequence are written in lowercase letters). Prime Star HS DNA polymerase (TaKaRa) was used for the PCR amplification. The 753-bp purified PCR product was inserted into the pURI3-Cter vector using a restriction enzyme- and ligation-free cloning strategy (Curiel et al., 2011). The vector produces recombinant proteins having a 6-histidine affinity tag in their C-termini. Escherichia coli DH10B chemically competent cells were transformed, recombinant plasmids were isolated, and those containing the correct insert were identified by size, verified by DNA sequencing, and then transformed into $E$. coli BL21 (DE3) cells for expression.

\section{Lp_1760 Protein Purification}

Protein expression of the $l p \_1760$ gene was made using E. coli BL21 (DE3) cells as the host strain. Cells carrying the recombinant plasmid pURI3-Cter-1760 were grown at $37^{\circ} \mathrm{C}$ in Luria-Bertani medium containing $100 \mu \mathrm{g} / \mathrm{mL}$ of ampicillin on a rotary shaker $(200$ rpm) until an optical density at $600 \mathrm{~nm}$ of 0.4 was reached. Isopropyl- $\beta$-D-thiogalactopyranoside was added to a final concentration of $0.4 \mathrm{mM}$ and protein induction was continued at $22^{\circ} \mathrm{C}$ for $18 \mathrm{~h}$. The induced cells were harvested by centrifugation $(8,000 \times g, 15$ min, $\left.4^{\circ} \mathrm{C}\right)$. The cells were resuspended in phosphate buffer $(50 \mathrm{~m} M, \mathrm{pH}$ 7) containing $300 \mathrm{mM} \mathrm{NaCl}$ and disrupted by French press passages (3 times at 1,100 psi). The insoluble fraction of the lysate was removed by centrifugation at $47,000 \times g$ for $30 \mathrm{~min}$ at $4^{\circ} \mathrm{C}$ and the supernatant was filtered through a $0.2-\mu \mathrm{m}$ pore filter and then loaded onto a Talon Superflow resin (Clontech). The resin was equilibrated in phosphate buffer (50 $\mathrm{m} M, \mathrm{pH}$ 7) containing $300 \mathrm{mM} \mathrm{NaCl}$ and $10 \mathrm{mM}$ imidazole to improve the interaction specificity in the affinity chromatography step. The bound enzyme was eluted using $150 \mathrm{mM}$ imidazole in the same buffer. The purity of the enzyme was determined by SDS-PAGE in Tris-glycine buffer. Fractions containing the His6tagged protein were pooled, dialyzed against phosphate buffer $(50 \mathrm{~m} M, \mathrm{pH}$ 7) containing $300 \mathrm{mM} \mathrm{NaCl}$, and analyzed for esterase activity.

\section{Enzyme Assay}

Esterase activity was determined by a spectrophotometric method as described previously (Esteban-Torres et al., 2013); however, p-nitrophenyl butyrate (SigmaAldrich, Steinheim, Germany) was used as substrate. 


\section{Substrate Specificity, Optimum $\mathrm{pH}$ and Temperature, and Thermostability}

To investigate the substrate specificity of Lp_1760, activity was determined using different $p$-nitrophenyl esters of various chain lengths (Sigma-Aldrich) - pnitrophenyl acetate (C2), p-nitrophenyl butyrate (C4), $p$-nitrophenyl caprylate (C8), p-nitrophenyl laurate (C12), p-nitrophenyl myristate (C14), and $p$-nitrophenyl palmitate (C16) - as substrates, as described previously (Esteban-Torres et al., 2013). The enzymatic activity of purified protein was also assayed against an ester library, which includes triacylglycerols such as triacetin and tributyrin (Esteban-Torres et al., 2013). p-Nitrophenol was used as $\mathrm{pH}$ indicator to monitor ester hydrolysis colorimetrically. The screening was performed in a 96-well flat bottom plate (Sarstedt, Nümbrecht, Germany) as described previously (Esteban-Torres et al., 2013). Esterase activity was assayed in a $\mathrm{pH}$ range from 3.0 to 9.0 and at temperatures of $5,20,30,37$, $40,45,50,55,60$, and $65^{\circ} \mathrm{C}$, as described previously (Esteban-Torres et al., 2013).

\section{Effects of Additives on Lp_1760 Esterase Activity}

The effect of metals and ions on the activity of the esterase was assayed by incubation of the enzyme in the presence of each additive at a final concentration of $1 \mathrm{~m} M$ during $5 \mathrm{~min}$ at room temperature. Then the substrate was added and the reaction was incubated at $37^{\circ} \mathrm{C}$ (Esteban-Torres et al., 2013). The compounds analyzed were $\mathrm{MgCl}_{2}, \mathrm{KCl}, \mathrm{MnCl}_{2}, \mathrm{CuCl}_{2}, \mathrm{NiCl}_{2}$, $\mathrm{CaCl}_{2}, \mathrm{HgCl}_{2}, \mathrm{ZnCl}_{2}$, diethyl pyrocarbonate, Cys, SDS, dithiothreitol, Triton X-100, Urea, Tween 80, Tween 20, EDTA, dimethyl sulfoxide, phenylmethylsulfonyl fluoride, and $\beta$-mercaptoethanol.

In addition, the effect of the presence of several compounds present during cheese making and ripening was assayed. The effect of $\mathrm{NaCl}$ and $\mathrm{CaCl}_{2}$ was determined by adding $\mathrm{NaCl}$ at concentrations ranging from 0 to $25 \%$ (wt/vol) or $\mathrm{CaCl}_{2}$ from 0 to $10 \%$ (wt/ vol). Reaction mixtures were prepared as described for the temperature optimum experiments, but different volumes of $25 \% \mathrm{NaCl}$ or $\mathrm{CaCl}_{2}$ were added, and the volume of the buffer was adjusted accordingly to maintain the final reaction volume. Reactions mixtures were preincubated for $5 \mathrm{~min}$ at room temperature before the enzyme was added. After the reaction, the absorbance was measured. The effect of the presence of lactic acid was assayed at concentrations ranging from 0 to $5 \mathrm{~g} / \mathrm{L}$. Reaction mixtures were prepared by adding different volumes of the corresponding stock solution $(25 \mathrm{~g} / \mathrm{L})$.

\section{RESULTS AND DISCUSSION}

\section{Production and Characterization of Lp_1760 Esterase}

Lactobacillus plantarum is a flexible and versatile bacterial species that is encountered in a wide variety of environmental niches, including some dairy, meat, and plant fermentations. The ecological flexibility of $L b$. plantarum is clear by the observation that this species has one of the largest genomes known among lactic acid bacteria (Kleerebezem et al., 2003). This large genome codifies enzymatic activities that could develop a fundamental role in food fermentations, such as esterases or lipases. When the reported sequence of the $L b$. plantarum WCFS1 genome was analyzed, numerous open reading frames (ORF) encoding putative esterases or lipases were found. One of the first ORF present in all the available $L b$. plantarum genomes is $l p \_1760$, predicted to encode a $250-\mathrm{AA}$ sequence protein with a theoretical molecular mass of $28.8 \mathrm{kDa}$. The deduced AA sequence of Lp_1760 lacked an N-terminal secretion signal sequence suggesting that this enzyme is located intracellularly. The AA sequence of Lp_1760 showed a $56 \%$ identity to a putative lipase or esterase from Lactobacillus sakei 23K (accession Q38VR0) or a $52 \%$ identity to a hydrolase from Enterococcus faecalis ATCC 6055 (accession R3KRQ5; data not shown).

The $l p \_1760$ gene was cloned into the pURI3-Cter expression vector by a ligation-free cloning strategy described previously (Curiel et al., 2011). The vector incorporates the DNA sequence encoding hexa-histidine to create a His-tagged fusion enzyme for further purification steps. The $l p \_1760$ gene was expressed under the control of an isopropyl- $\beta$-D-thiogalactopyranosideinducible promoter. Cell extracts were used to detect the presence of overproduced proteins by SDS-PAGE analysis. An overproduced protein with an apparent molecular mass around $28 \mathrm{kDa}$ was apparent in cells harboring pURI3-Cter-1760 (Figure 1). The recombinant protein was purified by a metal affinity chromatography resin, and eluted with phosphate buffer (50 $\mathrm{m} M, \mathrm{pH}$ 7) containing $300 \mathrm{mM} \mathrm{NaCl}$ and $150 \mathrm{~m} M$ imidazole. The eluted His6-tagged Lp_1760 was dialyzed and observed as a single band on SDS-PAGE (Figure 1). Routinely, the yield of purification is about $8 \mathrm{mg} / \mathrm{L}$ of purified protein.

The purified Lp_1760 protein was biochemically characterized. Substrate specificity was determined using $p$-nitrophenyl-linked esters of various acyl chain lengths ( $\mathrm{C} 2$ to $\mathrm{C} 16)$ at $37^{\circ} \mathrm{C}$ (Figure 2). Lp_1760 showed activity on all the acyl esters assayed, exhibiting significant activity on $p$-nitrophenyl palmitate 


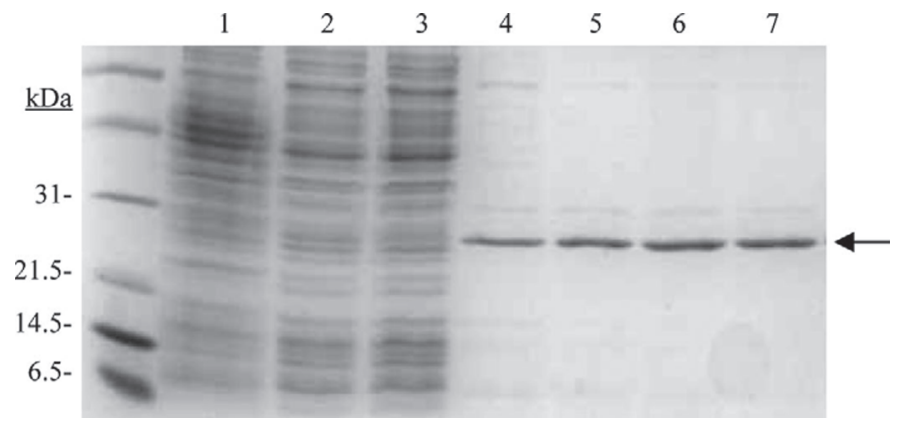

Figure 1. The SDS-PAGE analysis of the purification of Lp_1760 tributyrin esterase from Lactobacillus plantarum WCFS1. Analysis by SDS-PAGE of soluble cell extracts of Isopropyl- $\beta$-Dthiogalactopyranoside-induced Escherichia coli BL21 (DE3) (pURI3Cter) (lane 1) or E. coli BL21 (DE3) (pURI3-Cter-1760) (lane 2), flowthrough (lane 3 ), or fractions eluted after His affinity resin (lanes $4-7$ ). The arrow indicates the overproduced and purified protein. The gel was stained with Coomassie blue. Molecular mass markers are located at the left (SDS-PAGE Standards, Bio-Rad, Hercules, CA).

(C16). The observed activity on long-chain acyl esters confirmed that Lp_1760 is a true lipase. For the sake of comparison, we determined spectrophotometrically the kinetic parameters for the most reliable substrates, C2 and C4. In both cases, Lp_1760 exhibited hyperbolic Michaelis-Menten kinetics (not shown). The kinetic parameters are shown in Table 1. From the values of these parameters it can be deduced that the catalytic efficiency $\left(k_{\text {cat }} / K_{\mathrm{M}}\right)$ for $p$-nitrophenyl butyrate hydrolysis is around 2-fold that observed for $p$-nitrophenyl acetate hydrolysis, which is due to a lower $K_{\mathrm{M}}$ for $p$-nitrophenyl butyrate as $k_{\text {cat }}$ is essentially the same.

Esterase activity was revealed when the hydrolysis of esters present in the library were assayed. Lp_1760 showed highest activity on tributyrin, although in triacetin $30 \%$ of the tributyrin activity was observed (data not shown). Apart from tributyrin and triacetin, from the 40 esters assayed, only methyl hydroxyacetate, phenyl acetate, and vinyl octanoate were minimally hydrolyzed (data not shown). Tributyrin is a true fat and the simplest triglyceride occurring in natural fats and oils. The principal lipids of milk are triacylglycerides, which may represent up to $98 \%$ of the total lipids (Collins et al., 2003). Triacylglycerides are esters of glycerols

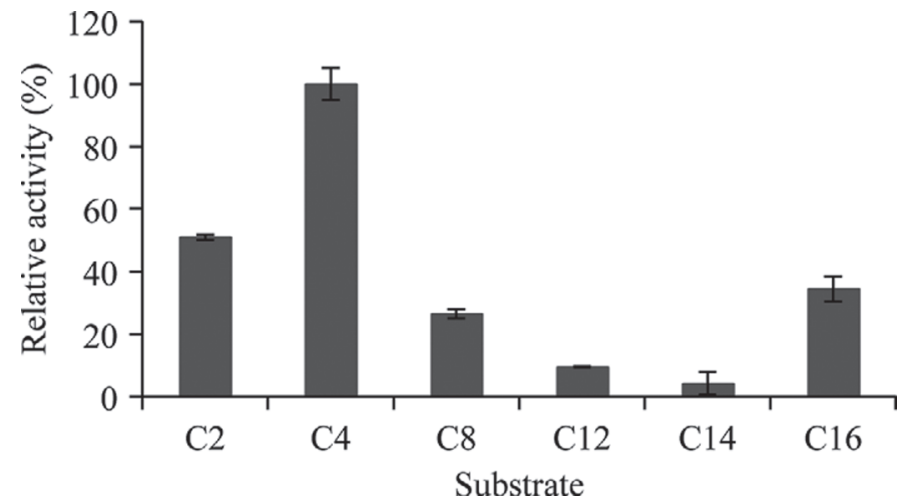

Figure 2. Substrate profile of Lp_1760 against chromogenic substrates ( $p$-nitrophenyl esters) with different acyl chain lengths $(\mathrm{C} 2=$ acetate; $\mathrm{C} 4=$ butyrate; $\mathrm{C} 8=$ caprylate; $\mathrm{C} 12=$ laurate; $\mathrm{C} 14=$ myristate; $\mathrm{C} 16=$ palmitate). The figure displays the relative specificities obtained toward different substrates, and lines on top of each bar represent the standard deviations estimated from 3 independent assays. The observed maximum activity was defined as $100 \%$.

composed of a glycerol backbone with 3 FA attached. Tributyrin is a common constituent of lipase testing media as it is easily dispersed in water (Samad et al., 1989). Tributyrin esterases from $L b$. plantarum have been isolated and partially purified previously (Andersen et al., 1995; Gobbetti et al., 1996, 1997; Lopes et al., 2002); however, they have not been genetically identified so far.

Regarding the dependence on $\mathrm{pH}$ of the hydrolytic activity, the lipase was active within the range between 3 and 8, exhibiting an optimal $\mathrm{pH}$ around 7 (Figure 3A). Lipases from $L b$. plantarum 2739 exhibited a similar optimal pH (7-7.5) (Gobbetti et al., 1996, 1997), whereas the purifed $L b$. plantarum MF32 lipase exhibited an optimal alkaline $\mathrm{pH}(\mathrm{pH}$ 9.3; Andersen et al., 1995); the extracellular lipase from $L b$. plantarum DSM 12028 showed an optimal acidic $\mathrm{pH}(\mathrm{pH} 5.5$; Lopes et al., 1999).

The influence of temperature on enzymatic activity was also determined (Figure 3B). The Lb. plantarum lipases characterized so far have optimal temperatures at 30 (Lopes et al., 1999), 35 (Gobbetti et al., 1996, 1997), or $37^{\circ} \mathrm{C}$ (Andersen et al., 1995). In contrast, maximal activity of Lp_1760 was observed at $45^{\circ} \mathrm{C}$.

Table 1. Kinetic parameters ${ }^{1}$ for $p$-nitrophenyl acetate (pNPA) and $p$-nitrophenyl butyrate (pNPB) hydrolysis by tributyrin esterase ${ }^{2}$

\begin{tabular}{lcccc}
\hline Substrate & $\begin{array}{c}V_{\max }(\mu \operatorname{mol} / \min \\
\text { per milligram })\end{array}$ & $\begin{array}{c}K_{\mathrm{M}} \\
(\mathrm{m} M)\end{array}$ & $\begin{array}{c}k_{\text {cat }} \\
\left(\mathrm{s}^{-1}\right)\end{array}$ & $\begin{array}{c}k_{\text {cat }} / K_{\mathrm{M}} \\
\left(\mathrm{s}^{-1} / \mathrm{m} M\right)\end{array}$ \\
\hline pNPA & $0.60 \pm 0.18$ & $2.17 \pm 0.86$ & $0.30 \pm 0.11$ & $0.14 \pm 0.05$ \\
pNPB & $0.46 \pm 0.09$ & $0.95 \pm 0.30$ & $0.23 \pm 0.06$ & $0.24 \pm 0.09$ \\
\hline
\end{tabular}

${ }^{1} V_{\max }=$ maximum reaction velocity; $K_{\mathrm{M}}=$ Michaelis constant; $k_{\text {cat }}=$ catalytic constant

${ }^{2}$ Enzyme activities were determined at $45^{\circ} \mathrm{C}$ in $50 \mathrm{~m} M$ sodium phosphate buffer, $\mathrm{pH}$ 7.0. Results are the mean value $\pm \mathrm{SD}$ from 3 independent experiments. 


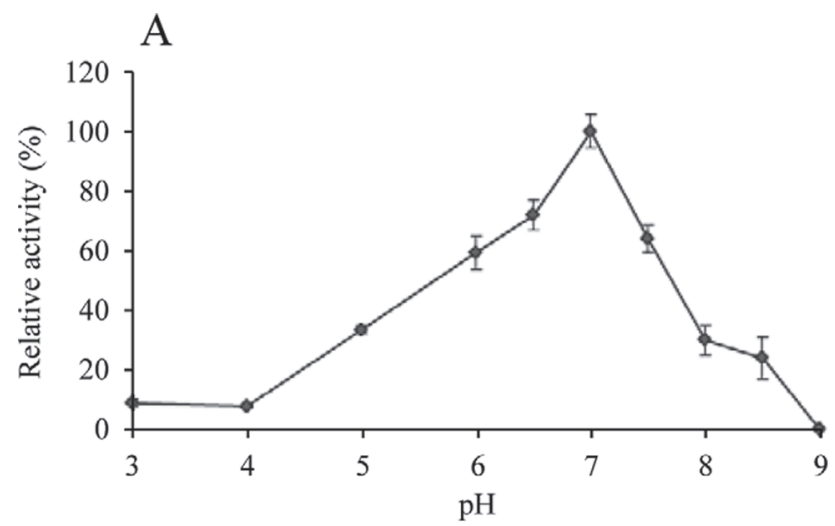

B
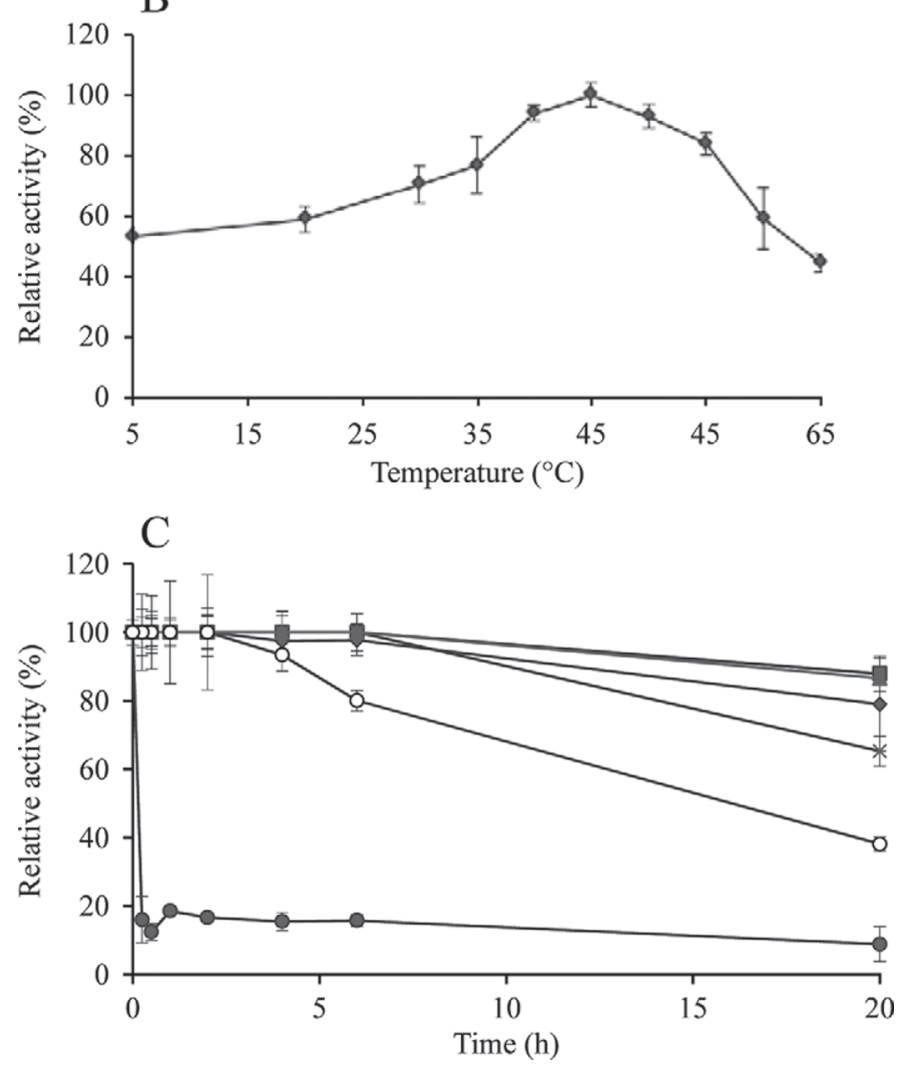

Figure 3. Biochemical properties of Lp_1760 tributyrin esterase. (A) pH-activity profile of Lp_1760. (B) Temperature-activity profile of Lp_1760. (C) Thermal stability profile for Lp_1760 after preincubation at $22^{\circ} \mathrm{C}(\diamond), 30^{\circ} \mathrm{C}(\boldsymbol{\square}), 37^{\circ} \mathrm{C}(\boldsymbol{\Delta}), 45^{\circ} \mathrm{C}(\times), 55^{\circ} \mathrm{C}(\mathrm{O})$, and $65^{\circ} \mathrm{C}(\bullet)$ in phosphate buffer $(50 \mathrm{mM}, \mathrm{pH} 7)$; at indicated times aliquots were withdrawn and analyzed as described in the Materials and Methods section. The experiments were done in triplicate. The mean value and the standard error are indicated. The percentage of residual activity was calculated by comparing with unincubated enzyme.

More interestingly, Lp_1760 exhibited more than 50\% of the maximal activity at $5^{\circ} \mathrm{C}$, and the activity only decreased to $40 \%$ at $65^{\circ} \mathrm{C}$. The high esterase activity observed within this broad range of temperatures makes this lipase a good candidate for industrial applications. Note that thermophilicity is related to the capacity of the enzyme to hydrolyze the substrate at high temperatures, whereas thermal stability is defined as an enzyme's ability to resist thermal unfolding in the absence of its substrate (Dotsenko et al., 2012). Figure 3C shows how Lp_1760 exhibited high thermal stability under prolonged incubation at temperatures up to $45^{\circ} \mathrm{C}$ (Figure 3C).

The effects of several ions and additives on Lp_1760 activity are provided in Table 2. Compared with the enzyme incubated in $50 \mathrm{~m} M$ phosphate buffer $\mathrm{pH} 7$, the enzymatic activity was not significantly increased by any of the ions or additives assayed. However, Lp_1760 activity was significantly inhibited by $\mathrm{Hg}^{2+}, \mathrm{Zn}^{2+}$, and $\mathrm{Cu}^{2+}$ ions and greatly inhibited by SDS or PMSF. Inactivation of the tributyrin esterase by PMSF suggests that a serine residue is involved in the catalytic mechanisms of the enzyme. This is highly probable, as most of the esterases and lipases have been previously characterized as having a Ser-Asp-His catalytic triad (Bornscheuer, 2002).

\section{Activity of Lp_1760 in the Presence of Conditions Found During Cheese Making and Ripening}

Unlike many processed food products for which stability is the key criterion, cheese is a biochemically dynamic product and undergoes significant changes during its ripening period. Lipolysis, or rather the extent to which it occurs during cheese ripening, is an important factor in the development of the correct and characteristic flavor profile of most cheese varieties. The use of exogenous lipases, microbial among them,

Table 2. Effect of additives on Lp_1760 tributyrin esterase activity

\begin{tabular}{lc}
\hline Addition & Relative \\
$(1 \mathrm{~m} M)$ & activity $(\%)$ \\
\hline $\mathrm{Control}$ & 100 \\
$\mathrm{KCl}$ & 89 \\
$\mathrm{HgCl}_{2}$ & 40 \\
$\mathrm{CaCl}_{2}$ & 106 \\
$\mathrm{MgCl}_{2}$ & 105 \\
$\mathrm{ZnCl}_{2}$ & 59 \\
$\mathrm{CuCl}_{2}$ & 51 \\
$\mathrm{NiCl}_{2}$ & 92 \\
$\mathrm{MnCl}_{2}$ & 90 \\
Tween 20 & 94 \\
Tween 80 & 78 \\
Triton X-100 & 100 \\
SDS & 11 \\
Urea & 115 \\
Dimethyl sulfoxide & 97 \\
Cysteine & 109 \\
Dithiothreitol & 101 \\
$\beta$-Mercaptoethanol & 90 \\
EDTA & 101 \\
Phenymethylsulfonyl fluoride & 17 \\
Diethyl pyrocarbonate & 97 \\
\hline
\end{tabular}


has been reported in the scientific literature for the manufacture of a variety of cheese to accelerate ripening or to develop characteristic flavors (Law, 2001; Hernández et al., 2005).

To ascertain the possible usefulness of Lp_1760 lipase during cheese making and ripening, the influence on its activity of the conditions and compound present on these processes was studied. Cheese-making processes subject microorganisms, and their enzymes, to adverse environmental conditions (such as acid or osmotic stress) which affect their technological performances. Lowering the $\mathrm{pH}$ in lactic acid fermentations may reduce the activity or completely inactivate enzymes that could generate either flavor components or flavor precursor compounds. The $\mathrm{pH}$ of cheese is controlled by the interactive effects of several critical factors, including the amount of lactic acid, calcium phosphate and proteins, the salt sensitivity of the starter culture, and the level and duration of salting (Hou et al., 2012). Figure 3 indicates that Lp_1760 exhibited $40 \%$ of its maximal activity at the $\mathrm{pH}$ usual during cheese making or ripening ( $\mathrm{pH}$ near 5).

In relation to temperature, cheese ripening temperature is characteristic of each cheese variety. As an example, Cheddar-type cheeses may be cured or ripened at up to $15^{\circ} \mathrm{C}$ for a period of several months, whereas Swiss-type cheeses are cured at 22 to $23^{\circ} \mathrm{C}$. The ripening temperature could be different from the storage or distribution temperature. It is recommended that pasteurized milk cheeses with $<50 \%$ moisture, traditional levels of salt, starter culture, $\mathrm{pH}$, and fat be allowed to be distributed at a temperature not exceeding $30^{\circ} \mathrm{C}$ (Johnson et al., 2009). At 15 to $30^{\circ} \mathrm{C}$, Lp_1760 showed 50 to $70 \%$ of its maximal activity, which makes it adequate for these processes.

Due to its industrial relevance, a better knowledge of the influence of compounds present during cheese making or ripening is important. The influence on Lp_1760 activity by compounds present in these processes (such as $\mathrm{NaCl}$, lactic acid, or calcium chloride) was also studied.

One of the final steps in the cheese-making process is the addition of salts. In dry-salted cheese, such as Cheddar, the salt is added directly to the curds just before hooping and pressing. In other types of cheese, the salt is added by submersing the cheese in brine (up to $20 \% \mathrm{NaCl}$ ) for an appropriate period of time and allowing salt to penetrate slowly during brining and the subsequent storage period. Finally, some cheeses have salt rubbed on the outer side of the cheese (Johnson et al., 2009). The influence of $\mathrm{NaCl}$ on Lp_1760 activity has been analyzed. Salt concentrations up to $10 \%$ increase lipase activity (Figure 4A). Contrarily, concentrations higher than $10 \%$ partially inhibited es-
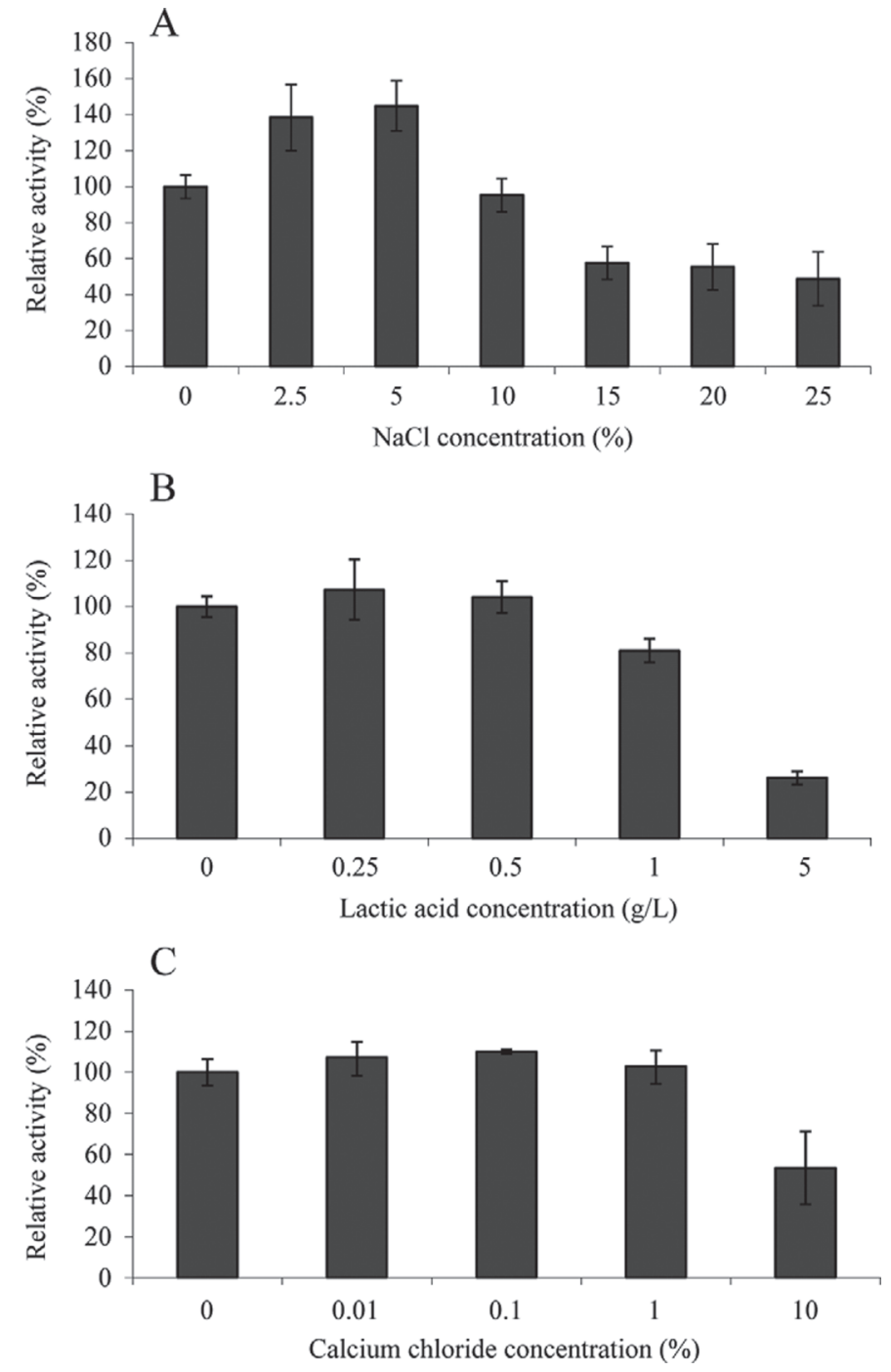

Figure 4. Activity of Lp_1760 esterase in the presence of compounds found during the cheese-making process. Relative activity of Lp_1760 after incubation in the presence of sodium chloride (A), lactic acid (B), and calcium chloride (C) at the concentrations indicated. The activity of the enzyme in the absence of the compound was defined as $100 \%$. The experiments were done in triplicate. The mean value and the standard error are shown.

terase activity; however, Lp_1760 retained half of the maximal activity at a $25 \% \mathrm{NaCl}$ concentration. At salt concentrations usual on final cheeses, the activity of Lp_1760 is increased.

In relation to lactic acid, starter bacteria are used to ferment the lactose to lactic acid. The rate and extent of acid development is controlled by the cheese maker to produce the final desired body, texture, and flavor characteristics of the cheese. Total lactate levels increased significantly with ripening time. The increase in lactate content with ripening time is consistent with the decrease in lactose levels, which is metabolized to lactic acid during ripening by starter and nonstarter bacte- 
ria. Lactate content from 1 to $1.5 \%$ (wt/wt) has been described during ripening of Cheddar cheese (Hou et al., 2012). At these lactic acid concentrations, Lp_1760 exhibited fully enzymatic activity (Figure 4B).

Calcium chloride is usually added to cheese-milk during cheese making to assist coagulation, improve the cheese-making process, or increase the yield. The normal range of calcium addition spans from 0 to $0.5 \mathrm{~g} / \mathrm{L}$ (Ong et al., 2013). Calcium chloride concentrations up to $0.1 \mathrm{~g} / \mathrm{L}(1 \%)$ did not affect Lp_1760 activity (Figure $4 \mathrm{C})$. The activity showed by Lp_1760 suggests that this esterase could play a role in modulating flavor profile during cheese ripening.

The obtained results indicated that Lp_1760 is a tributyrin esterase that retains activity under conditions commonly found during cheese making and ripening, such as cold temperature, acidic $\mathrm{pH}$, and the presence of salt, lactic acid, or calcium chloride. Another advantage for the potential use of Lp_1760 in cheese making is its thermostability. Further assays need to be done under combined conditions to further evaluate the effect of the simultaneous presence of different factors on Lp_1760 activity.

\section{CONCLUSIONS}

In the present study, the tributyrin esterase Lp_1760 from $L b$. plantarum, an important nonstarter LAB species which can be found during cheese ripening, was purified and biochemically characterized. Lp_1760 tributyrin esterase may contribute positively to cheese flavor development, as it shows marked activity on tributyrin and on p-nitrophenyl esters of FA. Lp_1760 exhibits high activity at the conditions (temperature and $\mathrm{pH}$ ) and in the presence of compounds (salt, lactic acid, or calcium chloride) found during cheese making and ripening. Based on the findings reported in our study, a tributyrin esterase or lipase of such characteristics may play a relevant role in flavor development during ripening, either produced in situ or added to milk or curd cheese manufacture.

\section{ACKNOWLEDGMENTS}

This work was financially supported by grants AGL2011-22745 and BFU2010-17929 (Ministerio de Economía y Competitividad), S2009/AGR-1469 (ALIBIRD; Comunidad de Madrid, Spain), and RM201200004 (Instituto Nacional de Investigación y Tecnología Agraria y Alimentaría). We are grateful to J. M. Barcenilla and M. V. Santamaría (both from Instituto de Ciencia y Tecnología de Alimentos y Nutrición). M. Esteban-Torres (Instituto de Ciencia y Tecnología de Alimentos y Nutrición) is a recipient of a Junta de
Ampliación de Estudios predoctoral fellowship from the Consejo Superior de Investigaciones Científicas.

\section{REFERENCES}

Andersen, H. J., H. Østdal, and H. Blom. 1995. Partial purification and characterization of a lipase from Lactobacillus plantarum MF32. Food Chem. 53:369-373.

Benavente, R., M. Esteban-Torres, I. Acebrón, B. de las Rivas, R. Muñoz, and J. M. Mancheño. 2013. Structure, biochemical characterization and analysis of the pleomorphism of carboxylesterase Cest-2923 from Lactobacillus plantarum WCFS1. FEBS J. 280:6658-6671. http://dx.doi.org/10.1111/febs.12569.

Bornscheuer, U. T. 2002. Microbial carboxyl esterases: Classification, properties and application in biocatalysis. FEMS Microbiol. Rev. 26:73-81.

Brod, F. C. A., J. Vernal, J. B. Bertoldo, H. Terenzi, and A. C. Maisonnave Arisi. 2010. Cloning, expression, purification, and characterization of a novel esterase from Lactobacillus plantarum. Mol. Biotechnol. 44:242-249.

Castillo, I., T. Requena, P. Fernández de Palencia, J. Fontecha, and M. Gobbetti. 1999. Isolation and characterization of an intracellular esterase from Lactobacillus casei ssp. casei IFLP731. J. Appl. Microbiol. 86:653-659.

Collins, Y. F., P. L. H. McSweeney, and M. G. Wilkinson. 2003. Lipolysis and free fatty acid catabolism in cheese: A review of current knowledge. Int. Dairy J. 13:841-866.

Crow, V. L., R. Holland, G. G. Pritchard, and T. Coolbear. 1994. The diversity of potential cheese ripening characteristics of lactic acid starter bacteria. 2. The levels and subcellular distribution of peptidase and esterase activities. Int. Dairy J. 4:723-742.

Curiel, J. A., B. de las Rivas, J. M. Mancheño, and R. Muñoz. 2011. The pURI family of expression vectors: A versatile set of ligation independent cloning plasmids for producing recombinant His-fusion proteins. Protein Expr. Purif. 76:44-53.

Dotsenko, G. S., O. A. Sinitsyna, S. W. A. Hinz, J. Wery, and A. P. Sinitsyn. 2012. Characterization of a GH family $3 \beta$-glycoside hydrolase from Chrysosporium lucknowense and its application to the hydrolysis of $\beta$-glucan and xylan. Bioresour. Technol. 112:345349.

Esteban-Torres, M., I. Reverón, J. M. Mancheño, B. de las Rivas, and R. Muñoz. 2013. Characterization of a feruloyl esterase from Lactobacillus plantarum. Appl. Environ. Microbiol. 79:5130-5136.

Fernández, J., A. F. Mohedano, E. Fernández-García, M. Medina, and M. Nuñez. 2004. Purification and characterization of an extracellular tributyrin esterase produced by a cheese isolate, Micrococcus sp. INIA 528. Int. Dairy J. 14:135-142.

Fernández, L., M. M. Beerthuyzen, J. Brown, R. J. Siezen, T. Coolbear, R. Holland, and O. Kuipers. 2000. Cloning, characterization, controlled overexpression, and inactivation of the major tributyrin esterase gene of Lactococcus lactis. Appl. Environ. Microbiol. 66:1360-1368.

Fox, P. F., and J. M. Wallace. 1997. Formation of flavour compounds in cheese. Adv. Appl. Microbiol. 45:17-85.

Gobbetti, M., P. F. Fox, E. Smacchi, L. Stepaniak, and P. Damiani. 1996. Purification and characterization of a lipase from Lactobacillus plantarum 2739. J. Food Biochem. 20:227-246.

Gobbetti, M., P. F. Fox, and L. Stepaniak. 1997. Isolation and characterization of a tributyrin esterase from Lactobacillus plantarum 2739. J. Dairy Sci. 80:3099-3106.

Hernández, I., M. de Renobales, M. Virto, F. J. Pérez-Elortondo, L. J. R. Barron, C. Flanagan, and M. Albisu. 2005. Assessment of industrial lipases for flavour development in comercial Idiazabal (ewe's raw milk) cheese. Enzyme Microb. Technol. 36:870-879.

Holland, R., and T. Coolbear. 1996. Purification of tributyrin esterase from Lactococcus lactis ssp. cremoris E8. J. Dairy Res. 63:131140.

Hou, J., J. A. Hannon, P. L. H. McSweeney, T. P. Beresford, and T. P. Guinee. 2012. Effect of curd washing on composition, lactose 
metabolism, $\mathrm{pH}$, and the growth of non-strater lactic acid bacteria in full-fat Cheddar cheese. Int. Dairy J. 25:21-28.

Johnson, M. E., R. Kapoor, D. J. McMahon, D. R. McCoy, and R. G. Narasimmon. 2009. Reduction of sodium and fat levels in natural and processed cheeses: Scientific and technological aspects. Compr. Rev. Food Sci. Food Saf. 8:252-268.

Kleerebezem, M., J. Boekhorst, R. van Kranenburg, D. Molenaar, O. P. Kuipers, R. Leer, R. Tarchini, S. A. Peters, H. M. Sandbrink, M. W. E. J. Fiers, W. Stiekema, R. M. Klein Lankhorst, P. A Bron, S. M. Hoffer, M. N. Nierop Groot, R. Kerkhoven, M. de Vries, B. Ursing, W. M. de Vos, and R. J. Siezen. 2003. Complete genome sequence of Lactobacillus plantarum WCFS1. Proc. Natl. Acad. Sci. USA 100:1990-1995.

Law, B. A. 2001. Controlled and accelerated cheese ripening: The research base for new technologies. Int. Dairy J. 11:383-398.

Liu, S.-Q., R. Holland, and V. L. Crow. 2001. Purification and properties of intracellular esterases from Streptococcus thermophilus. Int. Dairy J. 11:27-35.

Lopes, M. F., A. E. Cunha, J. J. Clemente, M. J. Teixeira Carrondo, and M. T. Barreto Crespo. 1999. Influence of environmental factors on lipase production by Lactobacillus plantarum. Appl. Microbiol. Biotechnol. 51:249-254.

Lopes, M. F., A. L. Leitao, M. Regalla, J. J. Figueiredo Marques, M. J. Teixeira Carrondo, and M. T. Barreto Crespo. 2002. Characterization of a highly thermostable extracellular lipase from Lactobacillus plantarum. Int. J. Food Microbiol. 76:107-115.
McSweeney, P. L. H., and M. J. Sousa. 2000. Biochemical pathways for the production of flavour compounds in cheeses during ripening: A review. Lait 80:293-324.

Navarro-González, I., A. Sánchez-Ferrer, and F. García-Carmona. 2013. Overexpression, purification, and biochemical characterization of the esterase Est0796 from Lactobacillus plantarum WCFS1. Mol. Biotechnol. 54:651-660.

Ong, L., R. R. Dagastine, S. E. Kentish, and S. L. Gras. 2013. The effect of calcium chloride addition on the microstructure and composition of Cheddar cheese. Int. Dairy J. 33:135-141.

Oterholm, A., Z. J. Ordal, and L. D. Witter. 1968. Glycerol ester hydrolase activity of lactic acid bacteria. Appl. Microbiol. 16:524527.

Oterholm, A., L. D. Witter, and Z. J. Ordal. 1967. Glycerol ester hydrolase activity of some lactic acid bacteria. J. Dairy Sci. 50:954

Oterholm, A., L. D. Witter, and Z. J. Ordal. 1972. Purification and properties of an acetyl ester hydrolase (acetylesterase) from Lactobacillus plantarum. J. Dairy Sci. 55:8-13.

Samad, M. Y. A., C. N. A. Razak, A. B. Salleh, W. M. Z. W. Yunus, K. Ampon, and M. Basri. 1989. A plate assay for primary screening of lipase activity. J. Microbiol. Methods 9:51-56.

Tsakalidou, E., and G. Kalantzopoulos. 1992. Purification and partial characterization of an extracellular esterase from Lactococcus lactis ssp. lactis strain ACA-DC 127. Lait 72:533-543. 